Article received on 22 September 2013

Article accepted on 30 September 2013

UDC: 793.31(497.11)

394.3(497.11)

78.085.7(497.11)

\title{
TRACING THE DISCIPLINE: EIGHTY YEARS OF ETHNOCHOREOLOGY IN SERBIA ${ }^{1}$
}

\author{
Selena Rakočević* * \\ University of Arts in Belgrade \\ Faculty of Music \\ Department of Ethnomusicology
}

\begin{abstract}
The interest for traditional dance research in Serbia is noted since the second part of the $19^{\text {th }}$ century in various ethnographical sources. However, organized and scientifically grounded study was begun by the sisters Danica and Ljubica Janković marked by publishing of the first of totally eight volumes of the "Folk Dances" [Narodne igre] in 1934. All eight books of this edition published periodically until 1964 were highly acknowledged by the broader scientific communities in Europe and the USA. Dance research was continued by the following generation of researchers: Milica Ilijin, Olivera Mladenović, Slobodan Zečević, and Olivera Vasić. The next significant step toward developing dance research began in 1990 when the subject of ethnochoreology was added to the program of basic ethnomusicological studies at the Faculty of Music in Belgrade and shortly afterward in 1996 in the Academy of Arts in Novi Sad. Academic ethnochoreological education in both institutions was established by Olivera Vasić.

The epistemological background of all traditional dance research in Serbia was anchored mostly in ethnography focused on the description of rural traditions and partly in traditional dance history. Its broader folkloristic framework has, more or less, strong national orientation. However, it could be said that, thanks to the lifelong professional commitment of the researchers, and a relatively unified methodology of their research, ethnochoreology maintained continuity as a scientific discipline since its early beginnings.
\end{abstract}

\footnotetext{
* Author contact information: selena@rakocevic.rs

1 This study is realized within the project 'Muzička i igračka tradicija multietničke i multikulturalne Srbije' ['Music and Dance Tradition of Multiethnic and Multicultural Serbia'], (reg. nr. 177024), financed by the Ministry of Education and Science of the Republic of Serbia, within a series of research in 2011-2015.
} 
Rakočević, S.: Tracing the Discipline: Eighty Years of Ethnochoreology ... (58-86)

The next significant milestone in the development of the discipline happened when traditional dance research was included in the $\mathrm{PhD}$ doctoral research projects within ethnomusicological studies at the Faculty of Music in Belgrade. Those projects, some of which are still in the ongoing process, are interdisciplinary and interlink ethnochoreology with ethnomusicology and related disciplines.

This paper reexamines and reevaluates the eighty years long tradition of dance research in Serbia and positions its ontological, epistemological and methodological trajectories in the broader context of its relation to other social sciences/humanities in the contemporary era of interdisciplinarity and postdiciplinarity.

Keywords: dance research, ethnochoreology, Serbia

\section{Introduction}

Although dance research, which could be termed by the overall term ethnochoreology (Kaeppler 2001: 361-367; Kealiinohomoku 2008: 18), maintained continuity as a methodologically and theoretically grounded discipline in Serbia, there are just a few papers which reevaluate its traits and achievements and (re)position it within the humanities. Efforts in discussing the ethnochoreological investigation in Serbia were made mostly during 1970s.

The recognition of dance research as a scholarly discipline in Serbian academia began in the early 1960s, when one of the founders of dance research, Ljubica Janković introduced to the academic communities two independent and autonomous scholarly disciplines - ethnomusicology and ethnochoreology (Janković 1964: 87-92). Ten years later (1975), Ljubica Janković also presented a system of dance notation and analysis which she developed with her sister Danica, to the broader ethnomusicological community in Europe and the USA emphasizing its advantages, as she strongly believed, 'both for specific scientific research and for broad cultural and educational needs' (Janković Lj. 1975: 32). Although she did not offer appropriate solutions, Olivera Mladenović pointed out the problems of developing comprehensive dance notation, classification system and unified reference terminology, which should be used among dance scholars in the early 1970s (Mladenović 1971: 303-306). A few years later, Milica Ilijin agreed with those standpoints and made an historical overview of 'development of ethnochoreology' in European countries (Ilijin 1973: 203-213). Elsie Ivancich Dunun, a co-founder with Allegra Fuller Snyder of a graduatelevel dance ethnology university curriculum in the USA in the 1970s (see more in Kurath 1960: 233-254; Kaeppler 2001: 364; Zebec 2009: 138) and scholar who has continuously explored dance traditions in the area of ex-Yugoslavia for 
decades, presented the basic trends in dance research in this country by the end of the 1970s (Dunin 1981: 1-5).

For the next twenty years there had been no effort to summarize and evaluate the theory and methods in dance research in Serbia until Dimitrije Golemović and Selena Rakočević presented one short overview of the history of the ethnomusicology and ethnochoreology in Serbia with some remarks about their possible future directions (Golemović and Rakočević 2008: 88-95). This paper was part of the panel session 'History and perspectives of national ethnomusicologies and ethnochoreologies in the Balkans', which was presented by ten scholars from Bulgaria, Greece, Macedonia, Bosnia and Herzegovina, and Serbia at the $39^{\text {th }}$ World Conference of the ICTM (International Council for Traditional Music) held in Vienna in 2007 and later published by the Bulgarian Academy of Science (Peycheva and Rodel 2008). In this publication several articles were devoted to the national scopes in dance research in southeastern Europe, ${ }^{2}$ opening the possibility for comparison of the similarities and differences in their epistemological and methodological orientations.

Although the mentioned papers offer a foundation toward discipline building, it seems that worldwide achievements in, let us use Judith Lynne Hanna's formulation made more than twenty years ago, the "scholarly field of dance" (Hanna 1992: 325), but also in the interdisciplinary and post-disciplinary alliances of the today's academia cause the need for reevaluation and repositioning of the eighty years long tradition of continuous dance research in Serbia. Theories, methods and subjects of research should be reevaluated within the discipline itself, but also within the humanities and toward other related disciplines.

\section{Historical traits}

As well as in other parts of Europe, the interest for traditional music and dance in Serbia started in the second part of the $19^{\text {th }}$ century together with the growing nationalistic movement and romantic interest for rural life. Dealing with traditional music consisted of collecting and transcribing traditional village songs for the purpose of saving them for the future generations or using them in compositions (see more in Marković 1994: 21; Marković, 2006: 8). On the other hand, since it was difficult to write down traditional dance patterns properly, interest for traditional dances in the $19^{\text {th }}$ century was focused toward

\footnotetext{
${ }^{2}$ Beside one devoted to Serbia, there are articles which present dance research in Bosnia and Herzegovina (Vasić and Panić-Kašanski 2008: 18-22, Macedonia (Opetceska-Tatarcevska 2008: 30-39) and Greece (Katsanevaki 2008: 49-75). For evaluation of the development and achievements of dance research in Croatia see more in Zebec 1996: 89-110; Ceribašić 1998: 49-65; Zebec 2009: 136-150.
} 
Rakočević, S.: Tracing the Discipline: Eighty Years of Ethnochoreology ... (58-86)

recording dance repertoires of distinct ethnographic regions of Serbia in the aim of differentiating their local cultural peculiarities.

The first data about traditional dances are found in the books of ethnographer Milan Đ. Milićević Kneževina Srbija [Principality of Serbia] (Milićević 1876) and Kraljevina Srbija [Kingdom of Serbia] (Milićević 1884). In those extensive monographies, which were ordered by the newly established Serbian goverment, ${ }^{3}$ Milan $Đ$. Milićević wrote about geographical and cultural specifities of different regions of Serbia. Although he did not have a model in domestic ethnography, Milićević included passages about the dance repertoires of each region by listing names of the individual dances, marking if they are 'old" or 'new" in that area and occasionally adding some short comments and simple verbal descriptions of the basic step patterns. Although the information in these books is deficient, they offer the possibility of perceiving continuity and/or change in the traditional dance repertoire.

The study 'Srpske narodne igre' ['Serbian folk games'] made by ethnologist Tihomir Đorđević in 1907 can be marked as the first conceptually grounded and methodologically based writing about traditional dances in Serbia (Đorđević 1907: 1-89). Relying on the rural Serbian language, Đorđević used the word 'igra' in a title of his study as a kind of an umbrella term and devoted his paper to different forms of human creative kinesthetic expression such as playing games and, dancing. Tihomir Đorđević considered all those forms of games as a manifestation of 'superfluous, unnecessary energy that appears in the human body" (Ibid: 1) and classified them in five groups. In order to distinguish dance from other forms of kinetic activities, Tihomir Đorđević conceived the term 'orske igre $\left[\right.$ literally: 'oro games ${ }^{6}$ ] to designate dance (ples). ${ }^{4}$ By using the emic term 'oro', which was used in the $19^{\text {th }}$ century and before in the village spoken languages in the areas of the southeastern Balkans (on the territories of today's eastern Serbia, Montenegro and Macedonia) as an expression for chain dances in circular formation (see more in Mladenović 1969: 477-478), Tihomir Đorđević from the very beginning focused dance research in Serbia into the local rural practice of performing dances in the circle. ${ }^{5}$ Although other dance formations were included occasionally in future investigations, the object of research was

3 The books were published in the period of establishing a modern national state as one of the first acts in (re)constructing national culture after several centuries of the Ottoman rule. ${ }^{4}$ The other groups are: 'viteške igre' ['games of the knights'],'zabavne igre' ['games for fun'], 'igre duha' ['games of the spirit'] and 'igre za dobit' ['games for profit'] (Đorđević 1907: 6).

${ }^{5}$ From the mid $20^{\text {th }}$ century the expression 'oro' is being repressed by the term 'kolo", which is now absolutely dominated on the whole territory of Serbia (Mladenović 1969: 477478). 
thus defined. Along with inauguration of the term, in his discussion on the concept of 'orske igre', Tihomir Đorđević separated them into two broad categories: religious dances and secular dances (Đorđević 1907:26). ${ }^{6}$ This terminology and classification modified by Olivera Vasić in 1988 (Vasić 1988: 459-462) has been used until recently, so it could be said that some of the theoretical considerations on traditional dances have a one-hundred years long tradition in Serbia. Since 'Srpske narodne igre" was the only study of Tihomir Đorđević devoted to the traditional dance practice, and despite its influence that it undoubtedly had to future researchers, its publishing cannot be considered as the beginning of the continuous and organized research that is, establishing a scientific discipline of its own.

\section{Tracing the discipline}

The first individuals who started to collect village dances for the basic purpose of saving them for the future were Tihomir Đorđević's nieces Danica and Ljubica Janković. The Janković sisters grew up in an intellectual Belgrade city family and were raised in the spirit of national patriotism and female emancipation. ${ }^{7}$ Both of them initially studied in the Faculty of Philology in Belgrade and worked as translators, literary theorists and professors. ${ }^{8}$ During the $1930 \mathrm{~s}$, however, they completely devoted themselves to the collection, recording and analysis of old peasant, that is, 'folk' dance. ${ }^{9}$ With the publication of the first of eight volumes of Narodne igre [Folk dances] in 1934, the modern era of ethnochoreological study began. These volumes, which are organized according to different regions of Serbia and ex-Yugoslavia, included detailed textual descrip-

\footnotetext{
${ }^{6}$ For the term secular dances (Serbian: 'svetovne igre '), Tihomir Đorđević used archaic expression 'svetske' igre (Literally, word ' svetske' means 'world' dances. It is a kind of word game that can not be adequately translated into English.).

7 Their mother Draga Janković was engaged in writing and painting watercolors and both of their uncles were highly educated. Academician Tihomir Đorđević was one of the founders of ethnology and folkloristics in Serbia (his study about folk games and dances is just one of his numerous scientific articles) and Vladimir Đorđević was a composer, one of the founders of the musical pedagogy and one of the first collectors of folk songs in Serbia.

8 They both were fluent in English and French languages, which they studied abroad after graduation. Danica studied English in London and Oxford (Ilijin 1959b): 171; Mladenović 1960: 250), while Ljubica was in Austria, Germany, England, and France (Mladenović 1974: 136). During the 1920s Ljubica was engaged in the Slovenian literature and even published a book Iz slovenacke književnosti [From Slovenian literature] in 1928 ( Mladenović 1974: 136).

9 According to Olivera Mladenović and Milica Ilijin, this turning point in their professional engagement has not happened accidentally, but it was generated by family environment and education (Ilijin 1974: 142; Mladenović 1974: 137).
} 
Rakočević, S.: Tracing the Discipline: Eighty Years of Ethnochoreology ... (58-86)

tions of some nine hundred dances, notations of their accompanying music, as well as more general discussions on the ethnographic context in which dances were performed. Along with this, the Janković sisters wrote a variety of articles on specific aspects on folk dance, which they incorporated in their books and in other publications. They discussed dances comparatively, with their history, dissemination and mutual influences and described basic context in which the dances were performed. Their work was recognized by the intellectuals and official authorities in Serbia, so Ljubica, who primarily worked as a school teacher, ${ }^{10}$ got a job in the Ethnographical Museum in Belgrade, where she worked from 1939 to 1950 (Mladenović 1974: 140). ${ }^{11}$ Beside that, due to her continuous and respected scholarly work, Ljubica was pronounced for corresponding (1963) and, ten yeas later, for regular member (1974) of the Serbian Academy of Sciences and Art (Mladenović 1974: 140).

Because of their excellent knowledge of English and French, but also their wide education and intellectual consistency, the Janković sisters had a wide correspondence with dance scholars from European countries, USA and Canada. ${ }^{12}$ Although they followed the latest worldwide achievements in the study of dance (see for example Janković 1939: 305-326), Danica and Ljubica Janković had a unique approach to the concept, methods and theoretical focus of the research, which they developed and promoted until the end of their lives.

Considering the fact that they were primarily devoted to collecting the oldest rural dances, but also their tight intellectual relationships with Tihomir Đorđević and great respect to his folkloristic achievements, the Janković sisters officially accepted term orska igra. However, they used this term just occasionally, fostering the expression "narodne igre" [literrary: 'folk games'] in their numerous articles in Serbian language and as a title for all eight of their books. ${ }^{13}$ No matter

10 After finishing the faculty in 1920, Ljubica worked in Fourth Male Gymnasium in Belgrade for a year, and then, from 1921 to 1939 in Second Female Gymnasium in Belgrade (Mladenović 1974 a): 136).

11 Danica worked as a school teacher in Tetovo in nowadays Macedonia and in Belgrade from 1924 to 1931. After that, she got a job at the University Library in Belgrade, where she stayed until 1951 (Mladenović 1960: 260-261).

12 Most of their correspondence is kept within the Legacy of Danica and Ljubica Janković in the National Library of Serbia. This huge legacy, which also includes Tihomir and Vladimir Đorđevic's manuscripts and other diverse inheritance, is currently under elaboration within the ongoing project Legacy of Danica and Ljubica Janković which will be finished by the end of 2016

13 The Janković sisters had ambivalent attitude toward precise defining the object of their research until the end of their professional activity. In the first of their books, the Janković sisters explicitly stated that they will consider in the text only 'secular oro folk dances" 
the term for the object of their research, they were devoted exclusivelly to the study of folk dance and not to other forms of gaming. ${ }^{14}$ In addition, it is important to note that consistency in the usage of the term 'folk' unambiguously and immediately positions the research activities of Danica and Ljubica Janković in the sphere of European folklore studies of the Romantic period (see more in Nahachewsky 2012: 31-32).

The collecting of dances by the Janković sisters was based on meticulously planned continuous field research, which they conducted between 1920s and 1950 s. ${ }^{15}$ Even though they had opportunities to observe various dance events, the epistemology of their field research was based primarily on the interview and questionnaire methods. They investigated mostly in the villages where they were looking for the best old dancers, who can demonstrate older practice (Janković 1952: 10). For the purpose of notating dances, they developed the system of notation, which according to their attitudes, can record dances from the Balkans in the most appropriate way (Janković 1975: 31) ${ }^{16}$ That's why they invented specific terminology in the Serbian language for different kinds of steps and dance motives in the first four of their books (Janković 1934, 1937, 1939, 1947). Their notation was mostly based on reduced verbal descriptions supplemented by some graphic signs. Each dance notation consisted of 'the pattern' (obrazac)

[svetovne orkse narodne igre] (Janković 1934: 4), but at the same time they retain the comprehensive and more general book's title Narodne igre. This ambivalent atitude occurs again thirty years later. In the article 'Etnomuzikologija i etnokoreologija' ['Ethnomusicology and ethnochoreology ${ }^{6}$ ] in which she introduced two new scholarly disciplines to the Serbian academia, Ljubica used exclusively the term narodne igre (Janković Lj. 1964: 90-92). However, within the manuscript 'Kombinovane metode etnokoreologije' ['Combined methods of ethnochoreology'], which Ljubica wrote for one of her lectures held in 1972, the research object of ethnochoreology was defined as orska igra. This manuscript is kept within the Legacy of Danica and Ljubica Janković in the National Library of Serbia.

${ }^{14}$ Danica and Ljubica Janković defined narodne igre comprehensivly, with 'general terms (Janiković 1939: 13). According to them it is 'anonymous, traditional, collective, ethnographic, folkloric, it mirrors the old traditional culture, it is expression and product of the soul of our people' ['narodna igra je: anonimna, tradicionalna, kolektivna, etnografska, folklorna, ogledalo stare tradicionalne kulture, izraz naše narodne duše'] (Ibid 1939: 13-14). Although they defined the phrase comprehensivelly, they refused to call anything a folk dance except an anonymously created dance performed in traditional settings (see more also in http://www.britannica.com/EBchecked/topic/212114/folk-dance).

${ }^{15}$ For most of their field research trips, as well as for the first three of their books, Danica and Ljubica Janković paid all expenses by themselves (Mladenović and Ilijin 1954: 159).

16 Although they were familiar with Labanotation and they had certain respect for this method of notation, the Janković sisters believed that it was not adequate for Serbian and Balkan folk dances because the specific relationship between dance and dance music, which they termed as 'Balkan phenomenon', cannot be notated precisely (Janković Lj. 1975: 31). 
Rakočević, S.: Tracing the Discipline: Eighty Years of Ethnochoreology ... (58-86)

and 'the analysis' (analiza) parts, the latter of which was organized by musical measures. In most of their books the Janković sisters published the main lines of dance music too. ${ }^{17}$

One of the main accomplishments of the Janković sisters' system of dance notation and analysis which influenced in a great measure further ethnochoreological investigation in Serbia is their structural approach to dance. In the aim of classification, comparison, systematization and, historical observation they conceptualized symmetrical and asymmetrical dance types according to typical structures that is, dance models (Janković, 1949: 45-53; Janković, Lj. 1975: 33-37). The approach to dance analysis of the Janković sisters, which has been considered as scientifically based (Janković, Lj. 1975: 32) has similarities with structural dance analysis which would be developed among European dance scholars during 1960s and 1970s (Martin and Pesovár 1961: 1-41, 1963: 295332; IFMC 1974: 115-135). As far as it is known, the Janković sisters were not under the direct influence of other methods of dance analysis. However, although the system they developed was unique, their approach to dance analysis and way of thinking belongs to the so-called European choreological scholarly tradition by its basic research topics, methods and tools (see more in Giruchescu and Torp 1991:1-10).

Although they were primarily concentrated to the dance itself as a product that is, the phenomenon of movement, Danica and Ljubica Janković also wrote several detailed and comprehensive articles about different issues of social, ${ }^{18}$ ethnographic ${ }^{19}$ and even gender relations within folk dance practice. ${ }^{20}$ In most of their books they also published numerous photographs of the dancers and villagers in regional costumes.

Their basic attitude that old village dances should be recorded and preserved before their disappearance, which probably generated the initial reason for starting to research dance in the first place, Danica and Ljubica Janković strongly promoted several times (for example Janković 1934; 1-4; 1937: 11-33; 1951: 5-12).

17 Only the first book (Janković 1934) does not have accompanied melodic lines of the dances. Danica Janković published them in separate publication several years after the first book was published (Janković D. 1937).

${ }^{18}$ For example the article 'Psihološki činioci u našim narodnim igrama' ['Psychological factors in folk dances'] (Janković 1939: 14-20).

19 For example the articles 'Svadbarske igre u vezi sa svadbenim običajima u našem narodu' ['Wedding dances related to the wedding customs of our people'] (Janković 1939: 31-43) or 'Prilog proučavanju ostataka orskih obrednih igara u Jugoslaviji' ['Contribution to the study of the remains of ritual dances in Yugoslavia'] (Janković 1957).

${ }^{20}$ The article 'Žena u našim narodnim igrama' ['Woman in our folk dances'] (Janković 1948: 6-7). 
This approach to the collection of dances was undivided with the processes of consciously establishing national culture and constructing the feeling of national identity, which were part of the prevailing tendencies in the European folkloristic tradition (Giruchescu and Torp 1991: 1-2).

Due to the consistency of their scholarly work, unified methodology and theoretical achievements, there is no doubt that Danica and Ljubica Janković established a scholarly discipline of dance research in Serbia. Ljubica Janković not only was aware of it, but she appointed the scientific field she dealt with as ethnochoreology and marked its beginning in 1934 by publishing the first volume of Narodne igre (Janković Lj. 1964: 92). This point of view was also confirmed by Milica Ilijin (Ilijin 1973: 203-204).

\section{Second generation of scholars: contextual approach to dance}

The next generation of scholars was represented by Olivera Mladenović, Milica Ilijin, and Slobodan Zečević. Contrary to their predecessors, they were more contextually oriented and they left much fewer descriptions of particular dances in all of their published works. However, they were still occasionally occupied by writing detailed ethnographies of dance traditions of different regions of Serbia.

All three scholars, Mladenović, Ilijin and Zečević, were members of the Savez udruženja folklorista Jugoslavije (SUFJ) [Federation of Associations of Folklorists of Yugoslavia] and participated in the congresses, which this association organized in a different republic of Yugoslavia each year. That is how the on-going dance research from all parts of Yugoslavia including Serbia was presented among dance researchers, ethnomusicologists and other folklore scholars. Most of presented articles were included in collections of papers, which were published after any annual congress meeting. One of the most important achievements of these mutual scholarly discussions was the comparison about different notation systems that had been created between the 1930s and 1950s in each of republics of ex-Yugoslavia. The final result was the general national acceptance to include Rudolf Laban's system of dance notation - Kinetography Laban also known as Labanotation, in dance research (Rad Kongresa folklorista Jugoslavije 1958). Allong with this, the annual meetings of the foklorists gathered around the SUFJ were significant for scholars from ex-Yugoslavia republics not only because they were exposed to each other's scholarly work, but also to the local music and dance traditions of the hosting congress. These experiences were certainly a built-in enrichment to the developing the field of dance research in ex-Yugoslavia.

Even she, as the Janković sisters, primarily finished the Faculty of Philology in Belgrade, Olivera Mladenović worked as dance researcher and scholar al- 
Rakočević, S.: Tracing the Discipline: Eighty Years of Ethnochoreology ... (58-86)

most all of her professional life. After working several years as a school teacher before World War II, Olivera Mladenović was secretary and adviser in the National Ensemble of Folk Songs and Dances 'Kolo' until 1962, when she started to work at the Institute of Ethnography of Serbian Academy of Sciences and Arts (Vlahović 1988: 97; Radovanović 1988: 197). While working in the 'Kolo' Ensemble, the Ministry of Education of Serbia hired Olivera Mladenović to design a detailed questionnaire for the survey of folk dances in Serbia. Mladenović created it and also conducted its implementation all over Serbia. ${ }^{21}$ Application of this questionnaire represented a new approach to dance documentation. Various gathered data about dance were considered as a 'scientific document' (Vlahović 1988: 98) and was widely used not only by Mladenović's contemporaries including the Janković sisters (Ibid: 98), but also by many scholars in the future (for example Vasić 1990: 25-27; Ranisavljević 2011: 96).

In the late 1950s, Olivera Mladenović finished ethnological studies at the Faculty of Philosophy in Belgrade. She was one of the first scholars who completed the doctorate in the field of dance in Serbia in 1965 at the same faculty (Vlahović 1988: 98). Her dissertation Kolo u Južnih Slovena [Kolo among South Slavs] is a comprehensive survey of round and chain dances among the South Slavs. In this book, which is published several years later (Mladenović 1973), the phenomenon of kolo is traced historically, analyzed structurally by using verbal descriptions, photo and graphical illustrations, and discussed by social significance and semantics. Although she considered kolo as an archaic phenomenon, Olivera Mladenović paid substantive attention to its more recent functions and meanings during World War II and the period of establishing of the socialist Yugoslavia. By choosing the universal dance formation as the main object of her investigation and widening the territory of research to areas where the South Slavs live, Olivera Mladenović extended scopes of the national Serbian borders of the discipline building, but at the same time stayed within the national boundaries of other country, which was Yugoslavia.

Beside her dissertation, Olivera Mladenović published a number of articles in which she discussed different aspects of dance (1958: 263-280), some historical sources for dance research (1964: 204-209), methodology of ethnochoreology (1971: 303-306) or scholarly terminology which should be developed (1978, 477-481). Although it was not the primary focus of her professional activities, Mladenović also investigated dances 'in the field', where she applied,

21 This questionnaire, known as 'Questionnaire on the status of folk dances in the territory of the People's Republic of Serbia' [Anketa o stanju narodnih igara na teritoriji Narodne republike Srbije], is kept in the Institute of Ethnography in the Serbian Academy of Science and Arts. 
beside making interviews and questionnaires, the observation method and wrote detailed ethnographic overviews of the particular regions or customes she observed (see for example Mladenović 1954: 91-96; 1974 b): 91-107). Despite the fact that she was focused to village dancing in almost all of her papers, Mladenović was aware that ethnochoreological research should be widened in the scope of investigation of the "contemporary function' of dance (Mladenović 1971: 305). That's why she had a critical relationship to Đorđević's term orske igre and division he made (Ibid: 304). At the same time, by sticking to the term narodne igre, Mladenović expressed great respect and alligned conceptual relationship to the Janković sisters' scholarly legacy.

Working at the institutions of national importance certainly influenced Olivera Mladenović's research topics to some extent, as it was the case with dance scholarship in most of the East European countries (see more in Giurchescu and Torp 1991: 3; Buckland 2006: 7; Bakka and Karoblis 2010: 169-170), but nonetheless Olivera Mladenović contributed greatly to the establishment of ethnochoreology in Serbia in academic terms by opening areas of historical discourse in dance research by archival work, as well as looking at dance in wider social and cultural contexts.

An immediate associate of the Janković sisters and Olivera Mladenović was Milica Ilijin. Although Ilijin studied the French language at the Faculty of Philology in Belgrade, she also worked as a professor of physical education in her youth (Jovanović 2010: 205). Due to implementing folk dances in physical education and engagement in different folk dance ensembles as organizer and instructor, she got the job as a dance researcher at the Institute of Musicology of Serbian Academy of Sciences and Arts in 1950 where she stayed until retirement. As a successor of the research methodology of the Janković sisters, Milica Ilijin collected dances during numerous field research in Serbia and Montenegro and described around one hundred dances in the system of the Janković sisters ${ }^{6}$ verbal notation (Ibid: 206). ${ }^{22}$ Beside dances of the Serbian population, Ilijin also researched dance traditions of the ethnic minorities in Serbia (Slovaks, Hungarian, Romanians, Albanians and Turks) (for example Ilijin 1953 a) and b); 1959 b)), as well as some of the more recent forms of dancing such as the partisans" dances (Ilijin 1960).

${ }^{22}$ Milica Ilijin was one of the contributors in the book by Croatian ethnochoreologist Ivan Ivančan Folklor i scena [Folklore and scene], which is partly devoted to reconstruction of dance traditions of different 'dance zones' of ex-Yugoslavia (Ivančan 1971). In this book Ilijin wrote chapers devoted to dance traditions of Vojvodina, Kosovo, Montenegro and Serbia (67-70, 79-81, 81-83, 83-86). She also published one of her ethnographic articles together with Olivera Mladenović. It is devoted to the folk dances of the surroundings of Belgrade (Ilijin and Mladenović 1962:166-217). 
Rakočević, S.: Tracing the Discipline: Eighty Years of Ethnochoreology ... (58-86)

During the most intense scholarly activity of Olivera Mladenović and Milica Ilijin, European ethnochoreologists gathered around the Study Group on Folk Dance Terminology of the IFMC (International Folk Music Council) ${ }^{23}$ working on the system of universal analytical terminology and common method of structural and form dance analysis based on Labanotation (see more in Giurchescu and Kröschlová 2007: 21-53). Milica Ilijin joined this group in 1965 and took part in the joint publication in which the system was introduced (IFMC 1974: 115-135). Although she did not apply this system to the dance material she collected nor did she use Labanotation, Milica Ilijin certainly contributed greatly to the promotion of ethnochoreology as a consistent scholarly discipline in Serbia and ex-Yugoslavia by introducing this system of structural dance analysis to the wider folkloristic and academic community (Ilijin 1968: 393-394; 1973: 203-213).

The professional activity of Milica Ilijin also focused on various efforts in promoting folk dances in public: she worked as an instructor and lecturer at numerous folk dance workshops and seminars in ex-Yugoslavia and abroad (Jovanović 2002: 321), worked as adviser of many folk dance ensembles and colaborated with the "Kolo' Ensemble, where she set two choreographies of dances of the ethnic minorities of Serbia (Rusini and Slovaks) in 1956. ${ }^{24}$

Slobodan Zečević was an ethnologist. He worked in various cultural institutions and at the Institute of Ethnography until 1965 when he became the director of the Ethnographic Museum in Belgrade (Antonijević 1983: 185). His scholarly activities were focused primarily on the reconstruction of folk mythology, religion and rural rites, but also to dance..$^{25}$

Zečević's PhD dissertation, which he completed at the the Faculty of Philosophy in 1962 under the title Paganski elementi u srpskim obrednim igrama [Pagan elements in Serbian ritual dances] (Ilijin 1973: 206), is devoted to reconstruction of the system of the mythological beliefs and rural rites in the area of southeastern Serbia. Slobodan Zečević strongly believed that it is possible to disclose the system of the Serbian and South Slavs mythology and pagan religion through comparative analysis of data from literature, but, in at least equal measure, through interpretation of data gathered during field research (Zečević

${ }^{23}$ This Study Group changed the name in 1978 into the Study Group on Ethnochoreology (Giurchescu and Kröschlová 2007: 5) and IFMC changed the name into International Council for Traditional Music (ICTM) in 1981 (http://www.ictmusic.org/general-information).

24 Those are the choreographies Rusinska igra [Dance of Rusini] and Slovačke igre [Dances of the Slovaks] (http://www.kolo.rs/page.php?31).

25 According to memories of Zečević's son, Božidar, Danica and Ljubica Janković greatly influenced his father to focus his research interest to folk dance (Zečević B. 2008: 896). 
S. 2008 a): 56-59). ${ }^{26}$ This dissertation which is later published (Zečević S. 2008 b): 61-211), interprets rites and ceremonial dances through evolutionist perspective of the older European folkloristics, which was part of wide nation building processes of constructing ancient ethnic identity of the people (see more in Buckland 2006: 7). Through bold interpretations of a high level of hypothetical issues on metaphorical meanings of ritual dances, Zečević opened new epistemological perspective in dance research in Serbia, which was based on the generalizations and subjective elucidations.

Beside this study, Zečević devoted one of his books to historical survey of folk dances in Serbia (Zečević S. 1983), where he comparatively distinguished regional dance dialects through the conceptualization of five ethnochoreological areas (27-45), ${ }^{27}$ but also focused his attention to the historical overview of the older city dances (47-57) and general systematization of the traditional dance repertoire (133-154). Beside these two main publications, Zečević also wrote several ethnographic papers devoted to village dances in different regions in Serbia (for example Zečević S. 1972: 401-403)

Although not considered a ethnochoreologist, Slobodan Zečević contributed to dance research in Serbia by widening the object of the research to ritual and city dances, and widening ways of their interpretation, which influenced theoretical and conceptual considerations of some of his followers, especially Olivera Vasić.

\section{Ethnochoreology and academic education}

The next acknowledgement toward dance research in Serbia came about 1990 when the subject of ethnochoreology was added to the program of basic ethnomusicological studies at the Faculty of Music in Belgrade. ${ }^{28}$ Several years later, in 1996, ethnochoreology was also included in the ethnomusicology

26 Zečević promoted distinct 'ethnological discipline', which he called 'ethnomythology" (Zečević S. 2008 a): 56-59). According to his apprehensions, the methodology of ethnomythology consisted both of consulting ethnographic publication and intense field research, where he used various methods: intewiev, questionnaire, observation and recording (Ibid).

27 Those are: Pannonian ethnochoreological area, Central ethnochoreological area, Dinaric ethnochoreological area, Ethnochoreological area of the south of Serbia and Ethnochoreological area of Timok region.

${ }^{28}$ It should be mentioned here, that even though the dance has not been included within ethnology and anthropology studies at the Faculty of philosophy in Belgrade, dance choreographer Slobodan Džadžević defended PHD dissertation Folk dance and problem of its conservation at this faculty in 1993. This study is published in 2005 (Džadžević 2005). It should be repeated again that Slobodan Zečević, Olivera Mladenović and Olivera Vasić gained their PHD projects about dance at the very same faculty. 
Rakočević, S.: Tracing the Discipline: Eighty Years of Ethnochoreology ... (58-86)

studies at the Academy of Arts in Novi Sad. Ehnochoreology thus began to be institutionally acknowledged as a scholarly discipline. Academic ethnochoreological education both in Belgrade and in Novi Sad was established by Olivera Vasić. ${ }^{29}$

Olivera Vasić finished ethnology at the Faculty of Philosophy in Belgrade. In her youth, she was a folk dancer and teacher in a Belgrade folk dance enssemble "Gradimir' more than 10 years. ${ }^{30}$ According to her own words, one of the crucial influences on her professional orientation was acquaintance with the work of Ivan Ivančan, an ethnochoreologist from Croatia (Zakić and Rakočević 2011: 227). ${ }^{31}$ While working at the Ethnographic Museum in Belgrade, Olivera Vasić defended PhD dissertation at Faculty of Philosophy in 1988, with her field work subject devoted to village dances of the Podrinje region. This dissertation was published several years later (Vasić 1991).

The starting point of Olivera Vasić epistemological approach to folk dance investigation is the field research, where she applies the mixture of interview and observation, but also participation methods. Through intense and continuous field research Olivera Vasić investigated numerous regions of Serbia. For the purpose of comparative analysis of geographically oriented ethnography, Olivera Vasić used slightly modified Zečević's regionalization of Serbia, but she also went further in geographical systematization of folk dances through proposing diverse dance dialects of the national heritage (see more in Vasić 2001: 12-13; 2011: 227-230). Along with making universal generalizations, most of Olivera Vasić's particular field research projects were published as ethnographic monographies in books or individual articles (for example Vasić 1984, 1994, 1999, 2007 a)).

According to her attitudes, one of the main tasks of dance research is collecting old village dances and preserving them for future generations (Zakić and Rakočević 2011: 228). Considering the respect that she expresses for the Janković sisters' work (Vasić 2005 a): 16), Olivera Vasić persistently keeps the basic terminological and classificatory solutions of her predecessors and still

29 Olivera Vasić taught ethnochoreology at Academy of Arts in Novi Sad until 2007. She also established academic ethnochoreological education at Faculty of Music on 'Saint Cyril and Methodius' University in Skopje, Macedonia, where she taught from 1993 to 1995 and also at Academy of Art, University of Banja Luka in 1999, where she is still teaching (personal communication with Olivera Vasić).

${ }^{30}$ Most of the folk dance ensembles in Serbia were termed as cultural-artistic societies (sing. kulturno-umetničko društvo, KUD)

31 Olivera Vasić met Ivančan for the first time at the Summer Folklore School in the early 1970s, which Ivančan organized from 1963 (see more in Sremac 2010: 388-389; Zebec 1996: 99, footnote 20). Olivera Vasić attended this school until 1990. 
promotes the terms and concepts of igra and orska igra (Vasić 1988: 459-46; 2011: 95). However, instead of the expression folk, Olivera Vasić rather uses the term traditional dance (Zakić and Rakočević 2011: 228). ${ }^{32}$

One of main achievements, if not the crucial one, in a methodological approach of Olivera Vasić is the application of Labanotation. ${ }^{33}$ Besides incorporating the Labanotation in all of her books and articles, Olivera Vasić set learning of this dance notation as one of the main contents of all ethnochoreological courses at the ethnomusicological studies in Belgrade and in Novi Sad, but also other academic institutions where she worked. ${ }^{34}$ Beside faculties, Olivera Vasić also taught Labanotation during numerous seminars for folk dance teachers all over the country.

For the purpose of organized promotion and learning of folk dances, Olivera Vasić founded and led the Centre for Folk Dance Research of Serbia [Centar za proučavanje narodnih igara Srbije], which existed from 1990 to 2012.35 One of the main activities of this centre was organizing the seminars for learning folk music and dance once or twice per year (see more in Vasić 2007 b); Zakić and Rakočević 2011: 226-227). Because of those organized continious activities and nationaly oriented policy of promoting village folk dances from various regions of Serbia and among Serbs from the Diaspora, the Centre had a great influence on the staged folklore (Ibid: 230-231).

The Centre also contributed greatly in collection activities, through organizing numerous filed research of various regions of Serbia, esspecially those which have not been explored previously. On those field research trips, the Centre sent the most successful participants of the seminars, mostly folk dance

\footnotetext{
${ }^{32}$ The usage of the term 'traditional' instead of 'folk' (dance), the emphasis placed on an imagined community and the collective dimension of dance performance, is shifted to its historical continuity (see more in Nahachewsky 2012, 39). In ethnochoreology in Serbia, this change in the appointment of the research object was not essential, but merely terminological.

${ }_{33}$ Olivera Vasić learned Labanotation from Slovenian notator Bruno Ravnikar during the Summer Folklore School and applied it for the first time in the first of her books devoted to folk dances of Bujanovac region in 1980 (Vasić 1980).

${ }^{34}$ Within the ethnochoreological courses Olivera Vasić also insisted on the practical learning of folk dances not only from Serbia, but also from all regions of former Yugoslavia. She strongly believes that dance knowledge must be based not only on theoretical but, even more importantly, kinetic experience.

35 In 2013, this Centre was transformed into the Centre for Research and Revitalization of Traditional Dances in Serbia [Centar za istraživanje i očuvanje tradicionalnih igara Srbije, CIOTIS], which is an assosiation of dance scholars and choreographers. Olivera Vasić is still a head of the organization.
} 
Rakočević, S.: Tracing the Discipline: Eighty Years of Ethnochoreology ... (58-86)

teachers and choreographers, who thus also worked as folk dance collectors. In preserving the old village dances, the very important issue of the Centre policy was directed towards public presentations of the collected field research data though publishing of ethnographic monographies titled as Narodne igre Srbije. Građa [Fold dances of Serbia. Materials], which all included Labanotation, but also sounds and, occasionally video recordings of particular dances (Vasić ed. 1991-2012). ${ }^{36}$ Considering the fact that they learned Labanotation during Centre's seminars and that they participated in field research as collectors, many of dance notators in those books were folk dance teachers and choreographers (see more in Vasić 2005 a): 93), and they did not have the appropriate academic education in ethnology, ethnochoreology, nor dance notation.

In her own dance notations, Olivera Vasić focused on presenting the most typical, that is, invariant dance patterns of the particular geographical areas, but also on some of their variant appearances. This method enabled further comparison of the dissemination of particular step patterns and conceptualizations of dance types of Serbia, which was one of Olivera Vasić's main scholarly concerns (Vasić 2002: 156-177). ${ }^{37}$

Beside ethnographic and theoretical texts, Olivera Vasić also published a number of papers devoted to various subjects from ritual (2004) to different forms of 'survival' of folk dances in contemporary Serbian society (2005 b)), which she subjectively interpreted according to her personal attitudes and life experience (see more in Zakić and Rakočević 2011: 227-230). As regards to the amount of dance material she collected and the number of published articles and books, Olivera Vasić has been beyond any doubt one of the most prolific dance researchers in Serbia.

Although Olivera Vasić was not musically educated nor was she concerned by analysis of dance music, thanks to the fact that ethnochoreology was learned at the faculty of music, students' approach to dance research inevitably incorporated musical analysis and, as it was the case with ethnomusicology in Serbia, their approach was based on the triple paradigm: field research-transcription/

\footnotetext{
${ }^{36}$ A total of 33 monographies were published in the edition Narodne igre Srbije. Građa from 1991 to 2012.

37 Olivera Vasić influenced very much with her research topics on many of her students who, though not continuously engaged in dance research, were devoted during their studies to certain ethnochoreological problems. This time, let us mention the important original article of the ethnomusicologists Rastko Jakovljević 'Strukturalna analiza u etnokoreologiji i njena moguća primena na srpsko igračko nasleđe' ['Structural analysis in ethnochoreology and its possible application to the Serbian dance heritage'], which is dedicated to the conceptualization of dance models (Jakovljević 2003: 210-236).
} 
dance notation-analysis (Golemović and Rakočević 2008: 88). Analytical focus on dance texts was enabled through the use of Labanotation. It also opened the possibility of evolving structural dance analysis, which was developed by European scholars since 1960s (IFMC 1974: 115-135; Giurchescu and Kröschlová 2007 21-63) and introduced in Serbia by Milica Iljin (Ilijin 1968: 393-394). Although many researchers associated ethnochoreology and ethnomusicology since their establishment as scholarly disciplines (see more in Giurchescu and Torp 1991: 2-3; Janković Lj 1964: 90; Ilijin 1973: 203; Zebec 1996: 95), it can be said that ethnochoreology in Serbia was more than ever linked with folk music research during 1990s and early 2000s.

As the ethnomusicology student of the first-generation of Olivera Vasić in my $\mathrm{PhD}$ project, which was dedicated to traditional dances of the Banat Serbs, ${ }^{38}$ I tried to ontologically and methodologically interlink ethnomusicology and ethnochoreology as much as possible. That's why I termed the object of my research 'ples" [dance] and defined it as an inseparable syncretic unity of dance movements and music (see more in Rakočević 2004: 96-118). Beside making a comprehensive ethnography of traditional dances of the Banat Serbs, the main focus of my thesis was to develop the methodology of comparative dance and musical structural/form analysis, which should reveal some of the regularities of the processing of the dance movements and music within particular dance genres. ${ }^{39}$ I defended my dissertation in 2009 (Rakočević 2009) and published it two years later (Rakočević 2011). However, thanks to the involvement in the study groups of ICTM - Study Group on Ethnochoreology and Study Group on Music and Dance of Southeastern Europe - I've started to reexamine and modify my approach to dance research. In my current professional interests and proj-

\footnotetext{
38 The theme of my dissertation Tradicionalna igra i muzika za igru Srba u Banatu u svetlu uzajamnih uticaja [Traditional dance and dance music of the Banat Serbs in the light of mutual influences], which I signed in 2006, directly represents basically folkloristic and nationally oriented approach in dance/musical research: I was focused on the reconstruction and historical observation of the old village (traditional) dances of the majority population of one geographical area - the region of Banat. However, the main focus of the disertation is put toward developing an original comparative system of dance/musical structural and form analysis.

39 The traditional dance repertoire of the Banat Serbs I systematized in two general dance genres: kolo and couple dances (Rakočević 2011: 21). The subgenres of kolo dances are: autochthonous kolo dances from Banat (autohtona banatska kola), towncraft dances (varoško-esnafska kola) and kolos from Šumadija (šumadijska kola). The subgenres of couple dances are; so-called in two dances (po dvoje) and so-called turning dances (okretni plesovi) (Ibid: 21-27).
} 
Rakočević, S.: Tracing the Discipline: Eighty Years of Ethnochoreology ... (58-86)

ects I am trying to extend, together with my students and younger colleagues, ${ }^{40}$ the methodological and theoretical discourses of ethnochoreology in Serbia.

The primary tasks of contemporary ethnochoreological research in Serbia are to extend the object and modify methods of field research. The field research focused on the reconstruction of the various forms of rural dancing from the past, which dominated the ethnochoreological discourse in Serbia and was considered as main and the most important epistemological source for gaining academic knowledge about dance, should be extended in the direction of investigation of the particular dance events [plesni događaji] (see more in Torp 1989). The concept of dance event defined as 'a social occasion of a special kind' (Ronström 1989: 23) represents the immediate 'time/space experience' of particular dancing seen as fluctuation of 'energy", to put it in Allegra Fuller Snyder words (Fuller Snyder 1989: 1). ${ }^{41}$ This concept promoted among wider group of dance scholars during the symposium of the ICTM Study group on Ethnochoreology held in Copenhagen in 1988. It revealed the possibilities of deeper contextual analysis and therefore Copenhagen meeting has been perceived by some scholars a kind of turning point in dance research in Europe (Zebec 2009: 140). In Serbia, this concept has been applyed only the last few years.

During field research various methods and multiple sources of gaining dance knowledge should be interlinked (see more in Gore and Bakka 2007: 93-97). Making interviews and questionnaires have been traditionally applied as main field research methods in Serbia. However, the potentials of applying

${ }^{40}$ I teach ethnochoreological courses ar Faculty of Music in Belgrade and Academy of Arts in Novi Sad as an assistant professor, together with a full professor Olivera Vasić and younger colleagues, assistants Zdravko Ranisavljević (Belgrade) and Vesna Karin (Novi Sad). Currently on the Faculty of Music in Belgrade, which ethnomusicological doctoral studies are accredited according to Bologna academic system, there are three ongoing $\mathrm{PhD}$ projects which include dance as a object of research. Zdravko Ranisavljević is dealing with the semantics of the one of the most popular contemporary dance genres in Serbia in the project Semantika žanra 'kolo u tri' u plesnoj praksi Srba [Semantics of the genre 'kolo in three in the dance practice of the Serbs] (supervisors are Mirjana Zakic and Selena Rakočević), Vesna Bajić-Stoiljković is dedicated to the representational (staged) forms of folk dances within the PhD theme Procesi (re)definisanja strukturalnih, dramaturških i estetskih aspekata u scenskom prikazivanju tradicionalne igre i muzike u Srbiji [Processes of (re)defining the structural, dramaturgical and aesthetic aspects in the stage presentation of traditional dance and music in Serbia] (supervisor is Selena Rakočević), and Vesna Karin observes dance practice of the imigrants from Dinara mountain in Vojvodina in the $\mathrm{PhD}$ project Plesna praksa Dinaraca u Vojvodini [Dance practice of the Dinaric people in Vojvodina] (mentored by Dimitrije Golemović and Olivera Vasić).

${ }^{41}$ According to Andriy Nahachewsky, dance research should include 'the entire dance event', which means a broader elaboration of form, context and meaning of dance activity (Nahachewsky 2012: 11). 
other various types of structured conversations between the researcher (the interviewer) and the dancer (the interviewee) which have been largely worked out in cultural anthropology (see for example Bernard 2006: 251-317), ${ }^{42}$ should be yet explored in the future.

Even previous researches (Olivera Vasić at the first place) based their knowledge about dance of certain areas of Serbia on their own dance experience gained during various occasions and situations, method of participatory observation (see more in Bernard 2006: 342-386) has not been conceived, consciously applied, nor explored in all of its potential meanings. Concisely defined as 'a dialectic between experience and interpretation“ (Sklar 1999: 17), participatory observation method opens the discourse of the so-called first-person experience as a perceptual dimension of dance research (see more in Bakka and Karoblis 2010: 180-181). To put it in Deidre Sklar words, 'the way to approach the felt dimension of movement experience is through the researcher's own body, than bodily memory, with all its qualitative and associative nuances, is one of the dance ethnographer's primary resources' (Sklar 2000: 75). Conscious gaining and scholarly interpretation of such embodied understanding of dance might be one of the intriquing fields of future investigation.

Filming and dance notation, which have been traditionaly used in dance research in Serbia could still be efficient tools in collecting and analysing of various dance data (Bakka and Karoblis 2010: 170-172, 187). However, both of those methods (filming ${ }^{43}$ and the usage of Labanotation ${ }^{44}$ ) should be technically and methodologically improved not only in Serbia, but in dance scholarship worldwide.

42 This time I will pay your attention on the so-called explicitation interview, which is developed by French psychologist Pierre Vermersch. According to dance anthropologist Georgiana Weirre-Gore it is the interview 'in which the agent is replaced in the lived situation which is the object of the interview, under the controlled guidance of the researcher. Through remebering or reminiscing on this original situation, verbalisation concerning the subjective experience, including its affective and cognitive dimenstions, becomes possible'(Gore and Bakka 2007: 94).

${ }^{43}$ Sociologist Hubert Knoblauch points to the double potentials in filming as an ethnographic method (in the so-called videography): it provides technology for recording audiovisual events and technology for its analysis (see more in Knoblauch 2012: 252-253). Those methods in gaining knowledge about dance should jet to be explored not only in Serbia, but worldwide.

${ }^{44}$ Dance researchers from Serbia (Olivera Vasić, Selena Rakočević, Zdravko Ranisavljević, Vesna Bajić-Stoiljković and Vesna Karin) became members of the International Society for Kinetography Laban in 2011 for the first time. The innovation and new developments in Labanotation has begun to be applied within ethnochoreological courses within academic education in Belgrade and Novi Sad. 
Rakočević, S.: Tracing the Discipline: Eighty Years of Ethnochoreology ... (58-86)

All of mentioned field research methods should be interlinked, combined and reexamined depending on the epistemological choices of the researcher (Bakka and Karoblis 2010: 184). Allong with this, establishment of a systematicaly designed dance documentation centre in Serbia should be yet one of our main tasks in the future.

In short, as it is already pointed out, dance investigation should actuate wider and deeper contextual analysis and the research object should be expanded to all forms of dance expression. Not only dance which we term folk or traditional, but also various kinds of 'structured movement systems' (Kaeppler 2001: 362) inseparable from music that accompanies them might be the objects of ethnochoreological research. What makes dance research ethnochoreological is not only the object of the research, but rather ways and methods of its scholarly exploration. The concept of dance as an unbreakable sincretic unity of dance movements and dance music leads to the one of the already welltrodden (ethnochoreological) paths of networking dance research with (ethnomusicological) observation of dance music. ${ }^{45}$ The challenges of expanding and interlinking the skills and perspectives of dance anthropology, dance ethnology, dance ethnography and dance history, also represent one of possible (ethnochoreological) options of dance research. Regardless of the epistemological and methodological choices of researchers, which may be multiple, discipline building should be based both on the major theoretical achievements that are set within the discipline itself, but also beyond it, in the other humanities.

Despite various approaches to constructing knowledge about dance, which continiously exist among scholars worldwide (Gore and Bakka 2007: 93-97), I still believe that epistemological basis for (ethnochoreological) research of dance should include equally, let us recall Egil Bakka and Gediminas Karoblis‘s formulation, 'the dance realisations' and 'the dance concepts' ${ }^{46}$ and that ethno-

${ }^{45}$ Ethnochoreology could be considered as interdiscipline by itself combining dance and music research. Along with that metatheoretical consideration, both of those disciplines could be also considered as already-mixture of dance anthropology, dance ethnology, dance ethnography and dance history (ethnochoreology) and, on the other side, anthopology and musicology (ethnomusicology) (for interdisciplinarity in ethnomusicology see more in Solis 2012: 545).

46 Scandinavian scholars, dance researcher Egil Bakka and philosopher and dance researcher Gediminas Karoblis suggest that 'dance has two dimensions: the realization and the con-

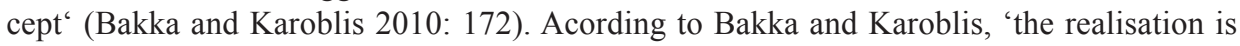
the actual dancing of a dance' (172) and dance concept is 'potential of skills, understanding, and knowledge that enables an individual or a dance community to dance that particular dance' (172-173). A simplified interpretation of those binaric dimensions of a dance could be related with text-context division in dance research. 
choreology as 'disciplined ${ }^{447}$ scholarly discipline needs to synthesize both the research of dance texts, contexts and their multiple meanings in the direction of developing 'the holistic study of dance' (Giurchescu and Torp 1991: 7).

\section{Final remarks}

This article traces disciplinary legacy of dance research in Serbia, which maintained continuity for the last eighty years. If we want to build and flourish ethnochoreology not only within the worldwide achievements in dance research but also as an independent scholarly discipline with unique methodological procedures and theoretical issues, ${ }^{48}$ 'selection of disciplinary context', to put it in Theresa Jill Buckland's words, 'is fundamental to both methodological procedures and analytical outcomes" (Buckland 2006: 8). By expanding the object of our research, but also by discussing and evaluating methods and perspectives of its investigation and exploration, ${ }^{49}$ we should try to work on developing reflexive and dialogic strategies of our research choices and be aware of possible implications that our attitudes could have (Buckland 2006: 8; Zakić and Rakočević 2011: 231). Making a balance between the scholarly study of dance and political implications of its preservation as an intangible cultural heritage, is still ahead of us.

\section{Acknowledgements}

I would like to thank my younger colleagues Zdravko Ranisavljević, Vesna Bajić-Stoiljković and Vesna Karin, who read the paper before I finished it and promptly gave their insightful comments and suggestions. I also feel really grat-

\footnotetext{
${ }^{47}$ Here I paraphrase the ethnomusicologist Timothy Rice and his call for new approach in ethnomusicology in which Rice claims that ethnomusicologists should lean more on theoretical achievements developed within ethnomusicology itself and not only in other humanistic disciplines (see more in Rice 2010: 318-324).

${ }_{48}$ Although I am aware that this kind of disciplinary parochialism can be interpreted as a consequence and at the same time the kind of opposition of global trends in interdisciplinary interlinking, and that it potentially has its limitations, I still believe that trodden terrain of dance research produces and requires fledged techniques and methods and that it could contribute with its theoretical achievements to the wide world of humanities.

${ }^{49}$ Even though not much discussed in this paper, theoretical aspects of dance research in Serbia should be developed more in the future. For example, gender relations are so far only touched in etnochoreological articles (see more in Janković 1948: 6-17, Vasić 2004: 116119, Rakočević 2011 b): 279-218) and they certainly should be explored much more and from different perspectives.
} 
Rakočević, S.: Tracing The Discipline: Eighty Years of Ethnochoreology ... (58- 86)

itude to Elsie Ivančić Dunin, who carefully read the text and, as she always did, enriched my attitudes about dance scholarship on the territory of ex-Yugoslavia with extraordinary patience and commitment. In her review of the paper, Mirjana Zakić raised useful and intriguing issues concerning the interpretation of modern developments within ethnochoreology as a scholarly discipline, which caused my deeper involving in final sections of the text. I am really grateful to all of them.

\section{REFERENCES}

Antonijević, Dragoslav, 'Pogovor' ['Afterword'], Srpske narodne igre, Beograd: Vuk Karadžić, 1983, 185-187.

Bakka, Egil; Karoblis, Gediminas, 'Writing a dance: Epistemology for dance research', Yearbook for traditional music, 42, Canberra: International Council for Traditional Music, 2010, 167-193.

Bernard, H. Russel, Research methods in anthropology. Qualitative and quantitative approaches, Lanham: AltaMira Press, 2006.

Buckland, Theresa Jill, 'Dance, history, and ethnography: frameworks, sources, and identities of past and present', Dancing from past to present. Nation, culture, identities, Madison: The University of Wisconsin Press, 2006, 3-24.

Cerebasić, Naila, 'Etnomuzikološka i etnokoreološka djelatnost Instituta tjekom devedesetih godina ' ['Ethnomusicology and ethnochoreologicy at the Institute during the nineties' Narodna umjetnost, 35/2, Zagreb: Institut za etnologiju i folkloristiku, 1998, 49-65.

Dunin, Elsie Ivancich, 'Basic trends in Yugoslav dance research'. Elsie Ivancich Dunin; Nancy Lee Chalfa Ruyter (eds.), Yugoslav dance. An introduction and list of sources available in United States libraries. Palo Alto: Ragusan Press, 1981, 1-5.

Đorđević, Tihomir, 'Srpske narodne igre“ ['Serbian folk dances'], Srpski etnološki zbornik, IX, Beograd: Srpska kraljevska akademija, 1907, 1-89.

Fuller Snyder, Allegra, 'Levels of event patterns - A theoretical model and its application to the Yaqui easter Ceremonies', The dance event: A complex cultural phenomenon, Copenhagen: ICTM, Study Group on Ethnochoreology, 1989, 1-20.

Giurchescu, Anca; Torp, Lisbet, 'Theory and methods in dance research: a European approach to the holistic study of dance', Yearbook for traditional music, 23, New York: Columbia University and International Council for Traditional Music, 1991, 1-10. 
Giurchescu, Anca; Kröschlová, Eva. 'Theory and method of dance form analysis'. Adrienne L. Kaeppler; Elsie Ivancich Dunin (eds), Dance structures. Perspectives on the analysis of human movement. Budapest: Institute for Musicology of the Hungarian Academy of Sciences, 2007, 21-53.

Golemović Dimitrije; Rakočević, Selena, 'Mapping the past and the future of Serbian ethnomusicology and ethnochoreology', Vienna and the Balkans, Lozanka Peycheva; Angela Rodel (eds.), Sofia: Institute of Art studies, Bulgarian Academy of Science, 2008, $88-95$.

Gore, Georgiana; Bakka, Egil, 'Constructing dance knowledge in the field: bridging the gap between realisation and concept', Re-thinking practice and theory, Proceedings Thirtieth Annual Conference, Society for Dance History Scholars co/sponsored with Congress on Research in Dance, Paris, 21-24 June 2007, Ann Cooper Albright; Dena Davida; Sarah Davies Cordova (comp.), 2007, 93-97.

IFMC Folk Dance Study Group. 'Foundation for the analysis of the structure and form of folk dance. A syllabus', Yearbook of the IFMC 6. Kingston, Canada: International Folk Music Council, 1974, 115-135.

Ilijin, Milica, Slovenske l'udove tance vo Vojvodine [Slovak folk dances in Vojvodina], Petrovec: Kultura, 1953 a), 1-110.

Ilijin, Milica, Mađarske narodne igre iz Vojvodine [Hungarian folk dances from Vojvodina], coauthorship with Margarita Debeljak), Novi Sad: Bratstvo i jedinstvo, 1953 b), $1-166$.

Ilijin, Milica, 'Nekrolog. Danica S. Janković' ['Necrologue. Danica S. Janković'], Glasnik Etnografskog instituta Srpske akademije nauka i umetnosti, VIII, Beograd: Srpska akademija nauka i umetnosti, 1959 a), 171-173.

Ilijin, Milica, 'Međusobni uticaji narodnih igara raznih etničkih grupa u Prizrenu' ['Interaction of folk dances of various ethnic groups in Prizren], Rad IV kongresa Saveza udruženja folklorista Jugoslavije Varaždin 1957, Zagreb: Savez udruženja folklorista Jugoslavije, 1959 b), 153-157.

Ilijin, Milica, 'Partizanske igre u Srbiji' ['Parisans' dances in Serbia'], Zbornik radova Srpske akademije nauka LXVIII, 3, Beograd: Etnografski institut, 1960, 204-230.

Ilijin, Milica, 'Uvodna reč za diskusiju o prednacrtu analize narodnih igara (Syllabus) '['Foreword to discussion of the draft of the analysis of folk dances (Syllabus)'], Rad XII kongresa Saveza udruženja folklorista Jugoslavije Celje 1965, Ljubljana: Savez udruženja folklorista Jugoslavije, 1968, 393-394.

Ilijin, Milica, 'Razvoj etnokoreologije' ['Developement of ethnochoreology'], Srpska muzika kroz vekove, Beograd: Galerija Srpske akademije nauka i umetnosti, 1973, 203-213.

Ilijin, Milica, 'Ljubica S. Janković' ['Ljubica S. Janković'], Narodno stvaralaštvo. Folklor, XIII, 1974, 141-144.

Ilijin, Milica and Mladenović, Olivera, 'Narodne igre u okolini Beograda', ['Folk dances in the surroundings of Belgrade'], Zbornik radova Srpske akademije nauka LXXV, 4, Beograd: Etnografski institut, 1962, 165-217.

Ivančan, Ivan, Folklor i scena [Folklore and scene], Zagreb: Prosvjetni sabor Hrvatske, 1971. 
Hanna Lynne, Judith, 'Dance', Ethnomusicology. An introduction, New York and London: W.W. Norton \& Company, 1992, 314-324.

Jakovljević, Rastko, 'Strukturalna analiza u etnokoreologiji i njena moguća primena na srpsko igračko nasleđe"['Strucutral analysis in ethnochoreology and its possible application on Serbian dance heritage'], Narodne igre Srbije. Građa, sveska 24. Beograd, Centar za proučavanje narodnih igara Srbije, FMU, 2003, 210-236.

Janković, Danica and Ljubica, Narodne igre [Folk dances], I, Beograd: authors' edition, 1934.

Janković, Danica and Ljubica, Narodne igre [Folk dances], II, Beograd: authors' edition, 1937.

Janković, Danica and Ljubica, Narodne igre [Folk dances], III, Beograd: authors' edition, 1939.

Janković, Danica and Ljubica, Narodne igre [Folk dances], IV, Beograd: Prosveta, 1947.

Janković, Danica and Ljubica, Narodne igre [Folk dances], V, Beograd: Prosveta, 1949.

Janković, Danica and Ljubica, Narodne igre [Folk dances], VI, Beograd: Prosveta, 1951.

Janković, Danica and Ljubica, Narodne igre [Folk dances], VII, Beograd: Prosveta, 1952.

Janković, Danica and Ljubica, Prilog proučavanju ostataka orskih obrednih igara u Jugoslaviji [Contribution to the study of the remains of ritual dances in Yugoslavia], Beograd: Srpska akademija nauka, posebna izdanja, knjiga CCLXXI, Etnografski institut, knjiga 8, 1957.

Janković, Danica and Ljubica, Narodne igre [Folk dances], VIII, Beograd: Prosveta, 1964.

Janković, Danica, Melodije narodnih igara za violinu i pevanje [Melodies of folk dances for violin and singing], Beograd: author's edition, 1937.

Janković, Ljubica, 'Etnomuzikologija i etnokoreologija' ['Ethnomusicology and ethnochoreology'], Spomenica u čast novoizabranih članova Srpske akademije nauka i umetnosti, 26, Beograd: Srpska akademija nauka i umetnosti, 1964, 87-92.

Janković, Ljubica, 'The system of the sisters Ljubica and Danica Janković for the recording, description and analysis of folk dances', Ethnomusicology, XIX/1, Ann Arbor: Society for ethnomusicology, 1975, 31-46.

Jovanović, Jelena, 'Sećanje na Milicu Ilijin', ['Remembering on Milica Ilijin'], Muzikologija, 2, Beograd: Muzikološki institut Srpske akademije nauka i umetnosti, 2002, 321.

Jovanović, Jelena, 'Milica Ilijin. Etnokoreolog', ['Milica Ilijin. Ethnochoreologist'], Muzikologija, 10, Beograd: Muzikološki institut Srpske akademije nauka i umetnosti, 2010, 205-210.

Kaeppler, Adrienne L, 'Ethnochoreology', The New GroveDictionary of Music and Musicians, second edition, Vol. 8, Oxford: Oxford University Press, 2001, 361-367.

Katsanevaki, Athena, 'Music and dance: Greek archives, institutions and initiatives. Aspects of research related to regional styles and the importance of the community', Vienna and the Balkans, Peycheva, Lozanka, Rodel, Angela (eds.), Sofia: Institute of Art Studies, Bulgarian Academy of Science, 2008, 49-75. 
Kaeppler L, Adrienne, 'Ethnochoreology', The New Grove Dictionary of Music and Musicians, 8, Oxford: Oxford university press, 2001, 361-367.

Kealiinohomoku, Joann W., Theory and methods for an Anthropological study of dance, Flagstaf, Arizona: Cross-Cultural Dance Research, 2008.

Knoblauch, Hubert, 'Introduction to the special issue of qualitative research: videoanalysis and videography', Qualitative research, 12, 2012, 251-254.

Kurath, Gertrude Prokosch, 'Panorama of dance ethnology', Current anthropology 1(3), 1960: 233-254.

Marković, Mladen, 'Etnomuzikologija u Srbiji' ['Ethnomusicology in Serbia'], Novi zvuk, 3, I/1994, 19-30.

Marković, Mladen, 'Kako je nastao prvi srpski etnomuzikolog' ['How appeared the first Serbian ethnomusicologist'], Miodrag Vasiljević - Život i delo, Nenad Ljubinković and Zorislava Vasiljević (eds). Beograd: Institut za književnost \& Udruženje građana 'Miodrag Vasiljević‘, 7-13.

Martin, György and Pesovár, Ernó, 'A Structural Analysis of the Hungarian Folk Dance (A

Methodological sketch)‘, Acta Ethnographica, 10, Budapest: A Magyar Tudományos Akadémia Néprajzi Közleményei. Academiae Scientarum Hungaricae, 1961, 1-41.

Martin, György and Pesovár, Ernó, 'Determination of Motive Types in Dance Folklore. 'Acta Ethnographica, 12, Budapest: A Magyar Tudományos Akadémia Néprajzi Közleményei. Academiae Scientarum Hungaricae, 1963, 295-332.

Milićević Đ, Milan, Kneževina Srbija [Principality of Serbia], Beograd: Državna štamparija, 1876.

Milićević Đ, Milan, Kraljevina Srbija [Kingdom of Serbia], Beograd: Državna štamparija, 1884.

Mladenović, Olivera, 'Narodne igre na Bele poklade u Velikoj Ivanči' [Folk dance in the village of Velika Ivanča], Glasnik Etnografskog muzeja, XVII, Beograd: Etnografski muzej, 1954, 91-96.

Mladenović, Olivera, 'Danica S. Janković (1898-1960)‘ ['Danica S. Janković (1898-1960)`], Glasnik Etnografskog muzeja, 22-23, Beograd: Etnografski muzej, 1960, 260-263.

Mladenović, Olivera, 'Jedan istorijski izvor za proučavanje naših narodnih igara 18. veka' ['One historical source for the study of our folk dances of the $18^{\text {th }}$ century'], Novi Sad: Rad vojvođanskih muzeja, 1964, 204-209.

Mladenović, Olivera, 'Neka pitanja metodologije klasifikacije i terminologije nasih narodnih igara' ['Some questions of the methodology of classification and terminology of our folk dances'], Rad XV Kongresa Saveza udruženja folklorista Jugoslavije, Sarajevo (Jajce): Savez udruženja folklorista Jugoslavije, 1971, 333-306.

Mladenović, Olivera, 'Akademik Ljubica S. Janković' ['Academician Ljubica S. Janković'], Glasnik Etnografskog instituta SANU, XXIII, Beograd: Srpska akademija nauka i umetnosti, 1974 a), 135-142. 
Mladenović, Olivera, 'Narodne igre Đerdapskog stanovništva' ['Folk dances of the inhabitans of the Đerdap Gorge'], Zbornik radova Etnografskog instituta, 7, Beograd: Etnografski institut Srpske akademije nauka i umetnosti, 1974 b), 91-107.

Mladenović, Olivera, 'Kolo i oro u našoj etnokoreološkoj terminologiji' ['Kolo and oro in our etnhnochoreological terminology'], Rad XVI Kongresa Saveza udruženja folklorista Jugoslavije, Cetinje (Igalo): Savez udruženja folklorista Jugoslavije, 1978, 477-481.

Mladenović, Olivera and Ilijin, Milica, 'Dvadeset godina rada sestara Janković na narodnim igrama' ['Twenty years of work on folk dances of the Janković sisters'], Zbornik Matice srpske, Serija društvenih nauka, 8, Novi Sad: Matica srpska, 1954, 158-160.

Nahachewsky, Andriy, Ukrainian dance. A cross-cultural approach, Jefferson, North Carolina \& London: McFarland \& Company.

Opetceska-Tatarcevska, Ivona, 'Macedonian ethnochoreology - a problem of continuity', $\mathrm{Vi}$ enna and the Balkans, Peycheva, Lozanka, Rodel, Angela (eds.), Sofia: Institute of Art Studies, Bulgarian Academy of Science, 2008, 30-39.

Peycheva, Lozanka and Rodel, Angela (eds.), Vienna and the Balkans, Sofia: Institute of Art Studies, Bulgarian Academy of Science, 2008.

Rad Kongresa folklorista Jugoslavije, Bjelašnica 1955. i Pula 1952, Zagreb: Kongres folklorista Jugoslavije, 1958.

Radovanović, Miljana, 'In Memoriam. Olivera Mladenović (1914-1988)' ['In Memoriam. Olivera Mladenović (1914-1988)‘], Glasnik Etnografskog instituta, XXXVI-XXXVII, Beograd: Etnografski institut Srpske akademije nauka i umetnosti, 1988, 197-201.

Rakočević, Selena, ‘Šta je to igra?. Etnokoreoleški pogled na terminološka i konceptualna određenja pojma' ['Dance - what it is? Ethnochoreological wiev on the terminological and conceptual questions'], Zbornik radova Dani Vlade Miloševića, Dimitrije Golemović (ed.), Banja Luka and Belgrade: Academy of Arts \& Vedes, 2004, 96-118.

Rakočević, Selena, Igra i muzika za igru Srba u Banatu u svetlu uzajamnih uticaja [Dance and dance music of the Banat Serbs in the light of their mutual relationships], $\mathrm{PhD}$ dissertation, Beograd: Katedra za etnomuzikologiju, Fakultet muzičke umetnosti, 2009.

Rakočević, Selena, Igre plesnih struktura. Tradicionalna igra i muzika za igru Srba u Banatu $u$ svetlu uzajamnih uticaja [Interweaving dance structures. Traditional dance and dance music of the Banat Serbs in the light of their mutual relationships], Beograd: Fakultet muzičke umetnosti, 2011 a).

Rakočević, Selena, 'Folklorna plesna praksa u Banatu: procesi ispoljavanja rodnog identiteta kroz ples', ['Dance practice of the Banat Serbs: Processes of manifesting gender identity through dance'], Srbija. Muzički i igrački dijalekti, Dimitrije Golemović (ed.), Beograd: Fakultet muzičke umetnosti, 2011 b), 179-218.

Ranisavljević, Zdravko, 'Stage performance and process of nationalization of the traditional dance patterns - The case of kolo u tri in the repertoire of the Serbian national ensemble Kolo', ICTM Study Group on Music and Dance of Southeastern Europe, Proceedings 2010 Symposium, Izmir: Ege Universitesi, 2011, 95-100.

Rice, Timothy, 'Disciplining Ethnomusicology: A call for a new approach', Ethnomusicology, 54 (2), 2010, 318-324. 
Ronström, Owe, 'The dance event - a terminological and methodological discussion of the concept'. The dance event: A complex cultural phenomenon, Copenhagen: ICTM, Study Group on Ethnochoreology, 1989, 21-29.

Sklar, Deidre 'All the dances have a meaning to that apparition: Felt knowledge and the danzantes of Tortugas, New Mexico', Dance research journal, 31, 2/1999, 14-33.

Sklar, Deidre, 'Reprise: On dance ethnography', Dance research journal, 32, 1/2000, 70-77.

Solis, Gabriel, 'Thoughts on an interdiscipline: Music theory, analysis, and social theory in ethnomusicology', Ethnomusicology, 56 (3), 2012, 530-554.

Sremac, Stjepan, Povijest i praksa scenske primjene folklornog plesa u Hrvata [History and practice of the scene application of folklore dances among Croats], Zagreb: Institut za etnologiju i folkloristiku, 2010.

Torp, Lisbet (ed.), The dance event: A complex cultural phenomenon, Copenhagen: ICTM, Study Group on Ethnochoreology, 1989.

Vasić, Olivera, Narodne igre i pesme okoline Bujanovca [Folk Songs and Dances in the Surroundings of Bujanovac], Beograd: Etnografski institut, specijalno izdanje, 21, 1980.

Vasić, Olivera, 'Igračka tradicija - problemi klasifikacije' ['Dance tradition - problems of classification'], Rad XXXV kongresa Saveza udruženja folklorista Jugoslavije. Titograd (Rožaje): Savez udruženja folklorista Jugoslavije, 1988, 459-462.

Vasić, Olivera, 'Narodne igre Peštersko-sjeničke visoravni' ['Folk dances of Pešter-Sjenica plateau'], Narodne melodije, igre i nošnje, Peštersko-sjeničke visoravni, Beograd: Radio Beograd, 1984, 191-314.

Vasić, Olivera, Narodne igre i zabave u titovoužičkom kraju [Folk dances and enertainments in the area of Titovo Užice], Beograd: Etnografski institut Srpske akademije nauka i umetnosti, 1990.

Vasić, Olivera, Igračka tradicija Podrinja [Dance tradition of Podrinje], Sarajevo: Književna zajednica 'Drugari', 1991.

Vasić, Olivera, Takovo u igri i pesmi [Takovo in dance and song], Gornji Milanovac: Tipoplastika, 1994.

Vasić, Olivera, 'Orsko nasleđe u Zaglavku i Timoku' ['Oro heritage in Zaglavak and Timok'], Knjaževac i okolina, Beograd: Etnografski muzej, 1999, 671-709.

Vasić, Olivera, 'Srce orskog nasleđa' ['The heart of oro heritage'], Folklor magazeine, Mićo Ćaldović (ed.), Beograd: Art Grafik, 2001, 12-13.

Vasić, Olivera, 'Osnovni igrački obrasci Srbije' ['The main dance patterns of Serbia'], Muzika kroz misao, Zbornik radova IV godišnjeg skupa nastavnika i saradnika Katedre za muzikologiju i etnomuzikologiju, Ivana Perković-Radak i Dragana Stojanović-Novičić (eds.), Beograd: Fakultet muzičke umetnosti, 2002, 156-177.

Vasić, Olivera, Etnokoreologija. Targovi [Ethnochoreoloogy. Traces], Beograd: Art grafik, 2004.

Vasić Olivera, Etnokoreologija. Sećanje [Ethnochoreology. Memory], Beograd. Art grafik, 2005 a). 
Rakočević, S.: Tracing the Discipline: Eighty Years of Ethnochoreology ... (58-86)

Vasić, Olivera, Etnokoreologija. Opstajanje [Ethnochoreology. Survival], Beograd: Art grafik, 2005. b)

Vasić, Olivera, Narodne igre jugozapadne Srbije [Folk dances of southeastern Serbia], Beograd: Art grafik, 2007 a).

Vasić, Olivera, Seminari 1990-2005 [Seminars 1990-2005],, Centar za proučavanje narodnih igara Srbije, Beograd: Fakultet muzičke umetnosti, 2007 b).

Vasić, Olivera, 'Igrački dijalekti seoskih igara Srbije u kolu' ['Dance dialects of Serbian rural dances performed in a kolo'], Srbija. Muzički i igrački dijalekti, Dimitrije Golemović (ed.), Beograd: Katedra za etnomuzikologiju, 2011, 91-178.

Vasić, Olivera; Panić-Kašanski Dragica, 'From the past towards the future: Six decades of Bosnian-Herzegovinian ethnomusicology and ethnochoreology', Vienna and the Balkans, Peycheva, Lozanka, Rodel, Angela (eds.), Sofia: Institute of Art Studies, Bulgarian Academy of Science, 2008, 18-22.

Vasić, Olivera (ed.), Narodne igre Srbije [Folk dances of Serbia]. Centar za proučavanje narodnih igara Srbije, Beograd: Fakultet muzučke umetnosti, 1991-2012.

Vlahović, Petar, 'Uz životno i naučno delo Olivere Mladenović' ['With the life and scientific work of Olivera Mladenovićc], Narodno stvaralaštvo - Folklor, XXVIII/1-4, Beograd: Savez udruženja folklorista Jugoslavije, 1988, 96-100.

Zakić, Mirjana and Rakočević, Selena, 'Institutionalizing traditional music and dance: a case study of post-Yugoslav Serbia', ICTM Study Group on Music and Dance of Southeastern Europe. Proceedings 2010 Symposium. Izmir: Ege Universitesi, 2011, 226-232.

Zebec, Tvrtko, 'Dance research in Croatia', Narodna umjetnost, 33/1, Zagreb: Institut za etnologiju i folkloristiku, 1996, 89-110.

Zebec, Tvrtko, 'Razvoj i primjena etnokoreologije u Hrvatskoj' ['Developemnt and application of ethnochoreology in Croatia'], Zbornik radova, VI Međunarodni simpozij 'Muzika u društvu', Sarajevo: Muzikološko društvo FbiH i Muzička akademija u Sarajevu, 2009, 136-150.

Zečević, Božidar, 'Pogovor. Pramen magle' ['Foreword. A wisp of fog'], Beograd: Službeni glasnik, 2008, 891-906.

Zečević, Slobodan, 'Pokladne igre u Gruži' ['Carnival dances in Gruža '], Rad XVII kongresa Saveza udruženja folklorista Jugoslavije Poreč 1970, Zagreb: Savez udruženja folklorista Jugoslavije, 1972, 401-403.

Zečević, Slobodan, Srpske narodne igre [Serbian folk dances], Beograd: Vuk Karadžić, 1983.

Zečević, Slobodan, 'Metodologija etnomitologije' ['Methodology of ethnomitology'], Beograd: Službeni glasnik, 2008 a), 56-59.

Zečević, Slobodan, 'Elementi naše mitologije u narodnim obredima uz igru' ['Elements of our mythology in traditional rites with dance'], Beograd: Službeni glasnik, 2008 b), 61211. 
New Sound 41, I/2013

\section{Internet Sources}

http://www.kolo.rs/page.php?31

http://www.britannica.com/EBchecked/topic/212114/folk-dance

http://www.ictmusic.org/general-information 